\title{
In situ histopathological and immunohistochemical characterization of rabies in the brains of naturally infected equines and bovines
}

\author{
Caracterização histopatológica e imuno-histoquímica In situ do \\ vírus da raiva em cérebros de equinos e bovinos naturalmente \\ infectados
}

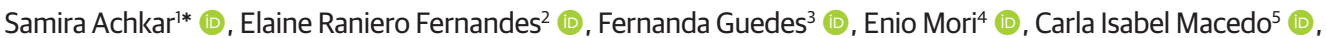 \\ Maria Irma Seixas Duarte ${ }^{6}$ \\ 'Biologist, MSc. Laboratório de Diagnóstico da Raiva, Instituto Pasteur, São Paulo, SP, Brasil \\ ²Biologist, PhD. Laboratório de Diagnóstico da Raiva, Instituto Pasteur, São Paulo, SP, Brasil \\ 3Biomedic, PhD. Laboratório de Diagnóstico da Raiva, Instituto Pasteur, São Paulo, SP, Brasil \\ ${ }^{4}$ Veterinary, PhD. Laboratório de Diagnóstico da Raiva, Instituto Pasteur, São Paulo, SP, Brasil \\ ${ }^{5}$ Veterinary, MSc. Laboratório de Diagnóstico da Raiva, Instituto Pasteur, São Paulo, SP, Brasil \\ ${ }^{6}$ Doctor, PhD. Departamento de Patologia, Faculdade de Medicina, Universidade de São Paulo - USP, São Paulo, SP, Brasil
}

\begin{abstract}
The present study sought to characterize the phenomena involved in the histopathology of rabies and to assess the presence and amount of viral antigen in situ in different brain regions of naturally infected equines and bovines. The histopathological examination showed several changes due to inflammation, being most often infected cells neurons. The neuronal degeneration involved $100 \%$ of cases, in addition to a diffuse lymphocytic Infiltration and gliosis, characterized by vasculitis and perivasculitis. The presence of Negri bodies was in most cases in discreet, and the fragments with higher concentrations of antigen by both techniques employed were the cerebellum and the brain stem. Immunohistochemistry test (IHC) demonstrated greater sensitivity when applied to samples of bovines. Our results showed that in 37.5\% of the total number of fragments analyzed, viral inclusions were not observed, however, was the presence of inflammatory process. In relation to the species, the fragments from bovine's animals showed a slight increase when examined under this feature. These findings highlight the importance of submitting samples from suspected animals for laboratory diagnostic, even when there are no apparent abnormal histological findings.
\end{abstract}

Keywords: rabies, equines, bovines, immunohistochemistry, FAT, histopathological changes.

\section{Resumo}

O presente estudo buscou caracterizar os fenômenos envolvidos na histopatologia da raiva e avaliar a presença e quantidade de antígeno viral in situ nas diferentes regiões cerebrais de equinos e bovinos naturalmente infectados. O exame histopatológico demonstrou várias mudanças devido à inflamação, sendo mais frequentemente infectadas as células neuronais. A degeneração neuronal foi observada em 100\% dos casos, além de uma infiltração linfocitária difusa e gliose, caracterizada por vasculite e perivasculite. A presença de corpúsculos de Negri foi observada na maioria dos casos de maneira discreta, e os fragmentos com maior concentração de antígeno, por ambos os testes empregadas foram o cerebelo e o tronco encefálico. O teste de Imuno-histoquímica (IHC) demonstrou maior sensibilidade quando aplicada em amostras de bovinos. Nossos resultados demostraram que em 37,5\% do número total de fragmentos analisados, inclusões virais não foram observadas, no entanto, havia processo inflamatório. Em relação à espécie, os fragmentos de bovinos demonstraram um ligeiro aumento quando examinado sob este aspecto. Esses achados destacam a importância de submeter amostras de animais suspeitos para diagnóstico laboratorial, mesmo quando não houver nenhum achado histopatológico anormal.

Palavras-chave: raiva, equinos, bovinos, imuno-histoquímica, IFD, alterações histopatológicas.
How to cite: Achkar, S., Fernandes, E. R., Guedes, F., Mori, E., Macedo, C. I., \& DuarteM. I. S. (2019). In situ histopathological and immunohistochemical characterization of rabies in the brains of naturally infected equines and bovines. Brazilian Journal of Veterinary Medicine, 41, e101419, doi: 10.29374/2527-2179.bjvm101419

Financial support: Instituto Pasteur and Departamento de Patologia da Faculdade de Medicina, Universidade de São Paulo - USP.

Conflict of interests: No conflict of interests declared concerning the publication of this article.

Received: December 05, 2018.

Accepted: July 07, 2019.

The study was carried out at Instituto Pasteur. São Paulo, SP, Brasil, and at the Departamento de Patologia, Faculdade de Medicina, Universidade de São Paulo - USP, São Paulo, SP, Brasil.

\section{*Correspondence}

Samira Achkar

Laboratório de Diagnóstico da Raiva, Instituto Pasteur de São Paulo

Av. Paulista, 393, Cerqueira César

CEP 01311-000 - São Paulo (SP), Brasil

E-mail:samira_achkar@yahoo.com.br
Copyright Achkar et al. This is an Open Access article distributed under the terms of the Creative Commons Attribution Non-Commercial License which permits unrestricted non-commercial use, distribution, and reproduction in any medium provided the original work is properly cited. 


\section{Introduction}

Rabies is a highly lethal zoonosis that affects the central nervous system (CNS) of mammals. It is caused by a virus in the family Rhabdoviridae, genus Lyssavirus, species Rabies lyssavirus (International Committee on Taxonomy of Viruses, 2016). The main reservoirs are carnivores and chiropterans, which can transmit the virus through saliva by biting, scratching and licking, of which biting is the most common.

Herbivores, especially bovines and equines, are dead-end hosts of the disease but can also transmit it accidentally. The main transmitter of rabies to these animals is the hematophagous bat Desmodus rotundus, and the regular finding of the antigenic variant specific to this species (AgV3) in samples from herbivores is evidence of the sensitivity of these animals to infection transmitted by bats (Mochizuki et al., 2012). However, the species Diaemus youngii and Diphylla ecaudata can also take part in the transmission cycle (Fundação Nacional da Saúde, 1996; Gonçalves et al., 2002).

The disease is considered endemic in certain regions of Latin America, and its economic cost runs to hundreds of millions of dollars a year. In addition to the loss of animals by rabies infection, secondary infections caused by hematophagous bats can affect herbivores and result in economic loss (Arelano-Sota et al., 1971; Schmidt \& Badger, 1979; Acha \& Szyfres, 1986; Johnson \& Montano Hirose, 2018). The economic cost of the diseases is compounded by the cost of post-exposure treatment of humans. Underreporting of the disease tends to undermine the effectiveness of control measures.

In 1966 a plan to combat rabies in herbivores was launched in Brazil. This is currently known as the National Program for the Control of Rabies in Herbivores (PNCRH) and is the responsibility of the Department of Animal Health in the Ministry of Agriculture, Fisheries and Supply (MAPA). Measures taken as part of the program include control of $D$. rotundus bats, vaccination of animals in endemic areas and submission of samples from suspected rabid animals for rabies testing (Brasil, 2009).

The incubation period for rabies transmitted by $D$. rotundus is typically around 30 to 90 days, or even longer (Brasil, 2008). Although the paralytic form predominates, the neurological signs may be confused with those of other diseases such as equine encephalomyelitis, toxoplasmosis, listeriosis and herpesvirus infections. Furthermore, the lesions do not have any specific macroscopic characteristics (Braund et al., 1987; Singh et al., 2017). It is therefore essential to submit samples of suspected rabid animals for laboratory diagnosis so that surveillance measures can be taken, particularly in areas where hematophagous bats are found. The World Health Organization (WHO) and the World Organization for Animal Health (OIE) recommended as gold standard test in the diagnosis of rabies the Fluorescent Antibody Test (FAT) (Dean et al., 1996), and for viral isolation, the Mouse Inoculation Test (MIT) (Koprowski, 1996) and/or the isolation in cell culture (Webster \& Casey, 1996). In addition, samples fixed in formalin can be tested by immunohistochemistry (IHC), which can therefore be used as another diagnostic tool for rabies. This technique is useful because it minimizes the possibility of artifacts due to autolysis that can compromise the viability of biological samples and consequently prevent conventional techniques being used.

The histopathological findings in rabies in herbivores are normally meningoencephalitis and meningomyelitis together with lymphocytic infiltrates (Langohr et al., 2003; Rech et al., 2006; Maxie \& Youssef, 2007; Marcolongo-Pereira et al., 2011). The areas most often affected by inflammation are the brainstem, cerebellum and spinal cord (Langohr et al., 2003; Fernandes \& Riet-Correa, 2007; Marcolongo-Pereira et al., 2011; Singh et al., 2017). Intracytoplasmic inclusions known as Negri bodies are pathognomonic of the disease (Swanepoel, 2004). The present study therefore sought to characterize the phenomena involved in the histopathology of rabies and to assess the presence and amount of viral antigen in situ in different brain regions of naturally infected equines and bovines.

\section{Materials and methods}

\section{Study population}

The rabies cases were represented by 16 brain samples from equines (Equus ferus, $\mathrm{n}=8$ ) and bovines (Bos taurus, $\mathrm{n}=8$ ) provided by the Rabies Diagnostic Laboratory at the Pasteur Institute of São Paulo between 2008 and 2009. The samples were selected at random using a positive result for rabies by FAT as the selection criterion. The control group consisted of ten 
brain samples (five from equines and five from bovines) selected using the absence of any infectious disease or neurological manifestation as the inclusion criterion. The equine samples came from the pathology laboratory at the São Paulo Jockey Club, and the cause of death was enterocolitis, laminitis, trauma and sudden death. Euthanasia was performed using sedation followed by administration of a general anesthetic, a neuromuscular blocking agent and, lastly, a death-inducing drug. The bovine samples came from a slaughterhouse, and the animals were therefore known to be healthy. The animals had been slaughtered humanely using a pneumatic penetrating stunner. The study was approved by the Pasteur Institute of São Paulo Committee for Ethics in the Use of Animals (CEUA/IP) under reference no. 08/2014.

\section{Analysis of epidemiological data}

The records for each sample were examined to identify the epidemiological history, including information such as age, gender, vaccination status, history of aggressive behavior and type of death.

\section{Database samples}

All 16 rabies 'cases used in this study had been previously confirmed by the FAT, and/or MIT. The methodology used in laboratory routine is based on the CNS processing of animals suspected. FAT was performed using polyclonal antibodies against rabies virus ribonucleoprotein (RNP) conjugated to fluorescein isothiocyanate (FITC) for Rabies virus (RABV) antigen detection in brain smears. For viral isolation, the suspensions 20\% (weight/volume) were prepared from the suspect animal nervous tissue and then inoculated in mice (MIT).

\section{Sample preparation}

Fresh fragments measuring approximately $6 \mathrm{~mm}$ were cut from the hippocampus (HC), cerebral cortex (CC), cerebellum (CB) and brainstem (BS), fixed in a 10\% buffered formalin solution for 24 hours and then embedded in paraffin blocks. Histological sections $4 \mu \mathrm{m}$ thick were made with a microtome and mounted on previously silanized slides.

\section{Histopathological examination}

Hematoxylin and eosin staining (HE) was used to identify histopathological changes, the degree of inflammation and the presence of cell inclusions in the brain regions described above.

\section{Testing for the presence of viral antigen}

For the immunohistochemical analysis (IHC), peroxidase-labeled streptavidin/biotin-complex (SABC) and anti-rabies polyclonal antibody provided by the Evandro Chagas Institute, Belém, PA, were used (Bourgon \& Charlton, 1987; Achkar et al., 2010; Fernandes et al., 2011). The IHC reaction was assessed using positive controls (brain fragments containing rabies virus antigen) and negative controls, which had all the reagents except the polyclonal antibody.

\section{Interpretation of the results}

The slides were examined under an ordinary optical microscope with a 10x eyepiece and 20x and 50x objective lenses. HE-stained sections revealed inflammatory changes, degenerative cell processes and the presence of inclusions, which were determined by semiquantitative analysis following Assis and Rosemberg (Assis \& Rosemberg, 1984) using a scale from 0 (absent) to 3 (intense). In the IHC-stained sections, positivity was determined by observing the distribution of antigen and the presence of viral inclusions. Four degrees reflecting the intensity of the reactions were adopted following criteria used by Carrieri et al. (2006). The sensitivity of the IHC technique was expressed as the positivity of IHC divided by the positivity of FAT, or S=PIHC/PFAT (sensitivity of IHC = positivity of IHC/positivity of FAT) (Forattini, 1980). All the data were tabulated using Excel.

All applicable international, national, and/or institutional guidelines for the care and use of animals were followed. This paper is part of the project "Immunopathologic characterization of rabies in situ in the central nervous system of naturally infected equines and bovines", which was approved by Ethics Committee on Animal Use of Pasteur Institute (Register 08/2014 - CEUA PASTEUR). 


\section{Results}

\section{Epidemiological data}

The epidemiological data showed that $55 \%$ of the animals had not been vaccinated against rabies. Most of the animals (70\%) died a natural death. Samples were divided practically equally between males and females, and 30\% each of bovines and equines had a history of aggressive behavior. Approximately half of the samples came from animals less than 24 months old.

\section{Histopathological alterations}

Histopathological examination revealed various inflammation-related changes (Table 1). The most commonly infected cells were neurons, and all the cases exhibited neurodegeneration, as well as, was observed in some cases, diffuse gliosis, vacuolation and lymphocytic infiltrates as evidenced by vasculitis and perivasculitis (Figure 1), and plasma cells and macrophages were also observed to a lesser degree. Meningitis, microglial nodules and neuronophagia were observed to varying degrees (Table 2). Brain tissue in the control group was unremarkable apart from the presence of mild ischemia and blood congestion, probably a consequence of the animal's death.

Negri bodies were observed in 21 and 19 CNS fragments of equines and bovines, respectively. They were more evident in Purkinje cells in the cerebellum and the brainstem.

Analysis of the 32 fragments from each species revealed that 23 (71\%) of the equine samples had mild inflammation and 7 (22\%) moderate inflammation. The brainstem was the most affected region and was followed by the cerebellum. Of the bovine samples, $14(44 \%)$ had mild

Table 1. Presence of histopathological changes in different regions of the CNS of equines and bovines naturally infected with the rabies virus.

\begin{tabular}{lccc}
\hline $\begin{array}{c}\text { Histopathological } \\
\text { changes }\end{array}$ & $\begin{array}{c}\text { HP } \\
\text { Equine Bovine }\end{array}$ & $\begin{array}{c}\text { CC } \\
\text { Equine Bovine }\end{array}$ & $\begin{array}{c}\text { CB } \\
\text { Equine Bovine }\end{array}$ \\
\hline Neurodegeneration & $8 / 88 / 8$ & $8 / 88 / 8$ & $8 / 88 / 8$ \\
Equine Bovine
\end{tabular}

HP: Hippocampus; CC: Cerebral Cortex; CB: Cerebellum; BS: Brainstem.
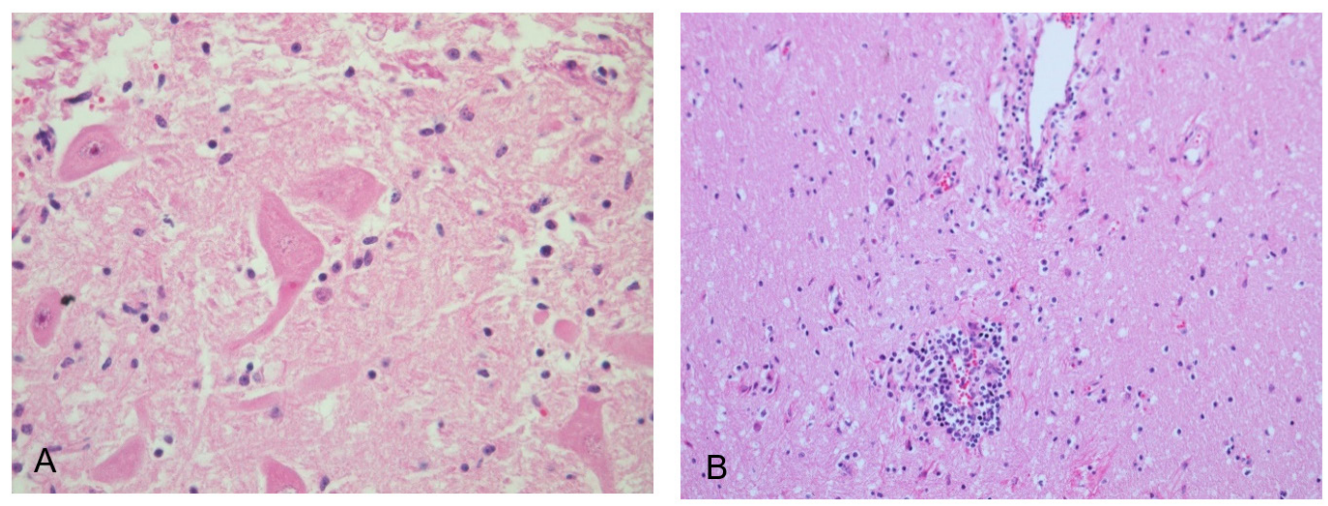

Figure 1. Degenerative process in bovine neurons and presence of Negri bodies (A) and fragment of equine hippocampus with vasculitis and perivasculitis (B) - HE 200X. 
Table 2. Distribution and degree of histopathological changes in different regions of the CNS of equines and bovines naturally infected with the rabies virus.

\begin{tabular}{lcccc}
\multicolumn{1}{c}{$\begin{array}{c}\text { Histopathological } \\
\text { changes }\end{array}$} & $\begin{array}{c}\text { HP } \\
\text { Equine Bovine }\end{array}$ & $\begin{array}{c}\text { CC } \\
\text { Equine Bovine }\end{array}$ & $\begin{array}{c}\text { CB } \\
\text { Equine Bovine }\end{array}$ & 11 \\
Equine Bovine \\
\hline Neuronophagia & 12 & 12 & 12 & 22 \\
Microglial Nodules & 12 & 11 & 00 & 00 \\
Necrosis & 00 & 00 & 01 & 11 \\
Meningitis & 12 & 12 & 0 \\
\hline
\end{tabular}

HP: Hippocampus; CC: Cerebral Cortex; CB: Cerebellum; BS: Brainstem. O: absent; 1: discreet; 2: moderate; 3: intense. Each degree assigned represents the average intensity of changes observed in all cases studied.

inflammation, 8 (25\%) moderate inflammation and 8 (25\%) intense inflammation. All four regions were affected equally.

A possible correlation between the presence of inclusions and inflammation was investigated in the four regions in both species. While in equines inflammation in the hippocampus was predominantly mild with moderate to abundant Negri bodies, in bovine inflammation in this region was also mainly mild but inclusions varied from sparse to moderate. The cortex samples from equines showed mild inflammation, and 50\% had inclusions varying from sparse to moderate, while in the cortex of bovine inflammation varied from mild to intense, and inclusions were present in moderate numbers. In the cerebellum, inclusions were sparse in both species, but inflammation was more intense in bovine. The same was observed for the brainstem (Figure 2).

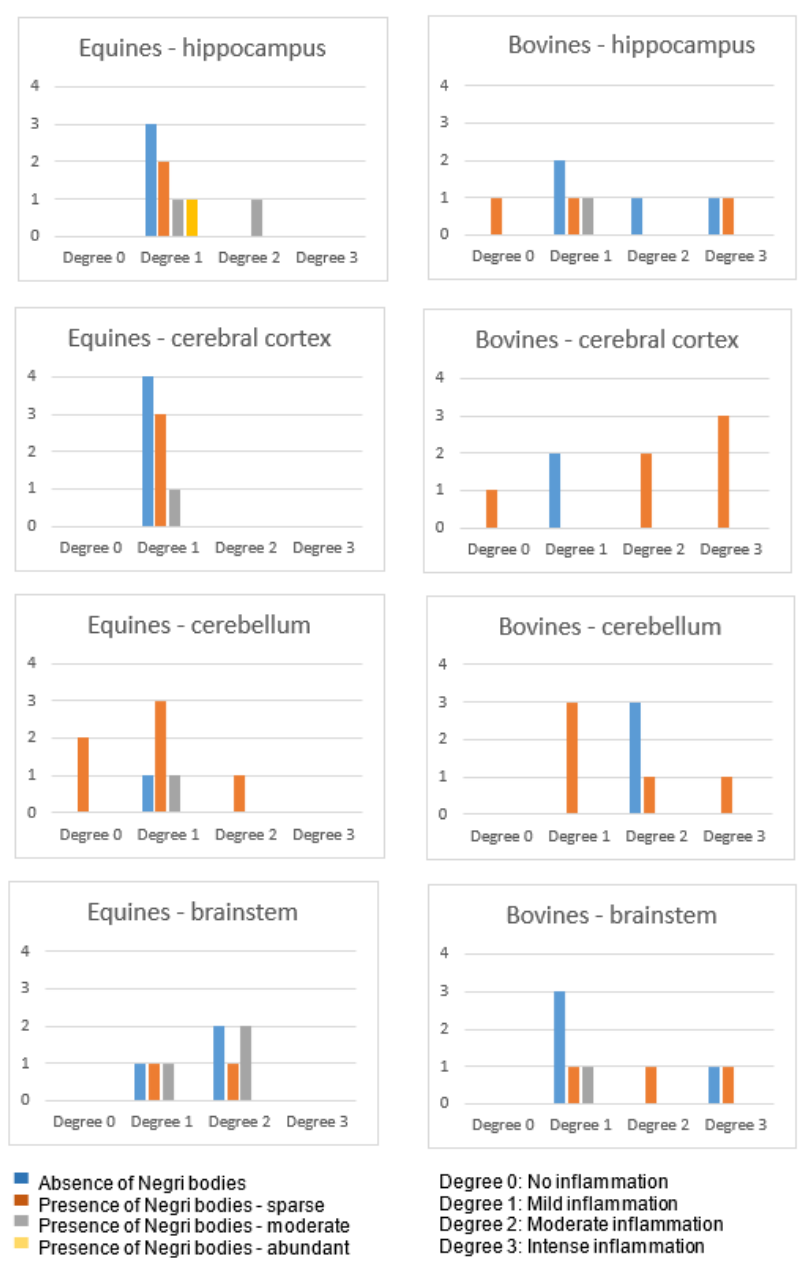

Figure 2. Correlation between the degree of inflammation and the presence of Negri bodies in fragments of hippocampus, cortex, cerebellum and brainstem from Equines and Bovines naturally infected with rabies virus. 


\section{Testing for the presence of viral antigen}

Two methods were used to investigate the presence of viral antigen: FAT and IHC. FAT revealed that viral antigen was heterogeneously distributed in neuronal cytoplasm in both species but that staining intensity was greater in bovine samples. IHC not only revealed rabies viral antigen with a granular appearance distributed multifocally and irregularly in the neuronal cell body and axons, but also clearly identified larger well-defined antigen aggregates characterizing viral inclusions. The regions with the greatest concentrations of antigen detected by both methods were the cerebellum and brainstem (Figure 3). Only one sample was negative by IHC; the sample was positive by FAT, but with low-intensity staining (Table 3). IHC was more sensitive for bovine samples (Table 4).
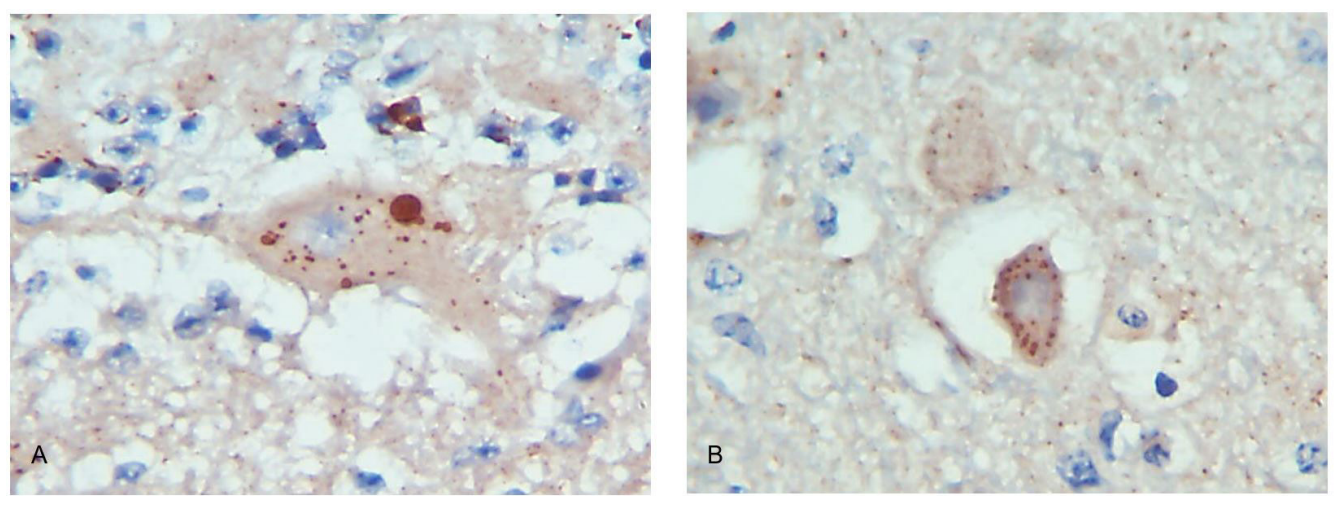

Figure 3. Negri bodies (brown immunostaining) in bovine cerebellum (A) and in equine brainstem (B) - IHC 400X.

Table 3. Distribution of antigenic rabies virus in samples of equines and bovines SNC submitted to tests of Immunohistochemistry (IHC) and Fluorescent Antibody Test (FAT).

\begin{tabular}{|c|c|c|c|c|c|c|c|c|}
\hline \multirow{2}{*}{$\begin{array}{l}\text { Sample } \\
\text { E/1532 }\end{array}$} & \multicolumn{2}{|c|}{$\begin{array}{l}\text { Hippocampus } \\
\text { FAT IHQ }\end{array}$} & \multicolumn{2}{|c|}{$\begin{array}{c}\text { Cerebral Cortex } \\
\text { FAT IHQ }\end{array}$} & \multicolumn{2}{|c|}{$\begin{array}{l}\text { Cerebellum } \\
\text { FAT IHQ }\end{array}$} & \multicolumn{2}{|c|}{$\begin{array}{l}\text { Brainstem } \\
\text { FAT IHQ }\end{array}$} \\
\hline & + & - & + & - & + & + & + & - \\
\hline $\mathrm{E} / 1594$ & ++ & - & ++ & + & ++ & ++ & ++ & + \\
\hline $\mathrm{E} / 1696$ & - & - & - & + & + & ++ & ++ & ++ \\
\hline $\mathrm{E} / 3357$ & + & - & + & - & + & + & + & + \\
\hline E/4833 & ++ & + & + & + & ++ & +++ & ++ & ++ \\
\hline E/5790 & + & - & + & - & + & - & + & - \\
\hline E/7955 & + & + & + & + & ++ & ++ & ++ & ++ \\
\hline E/9146 & + & - & + & + & ++ & ++ & ++ & + \\
\hline B/131 & + & + & + & + & + & ++ & +++ & + \\
\hline B/191 & ++ & + & ++ & ++ & ++ & ++ & ++ & ++ \\
\hline $\mathrm{B} / 514$ & +++ & ++ & +++ & +++ & +++ & +++ & +++ & +++ \\
\hline $\mathrm{B} / 586$ & +++ & + & +++ & ++ & +++ & +++ & +++ & ++ \\
\hline $\mathrm{B} / 633$ & + & + & + & + & ++ & + & ++ & + \\
\hline B/1052 & ++ & + & ++ & ++ & +++ & +++ & +++ & +++ \\
\hline B/11378 & + & + & + & + & ++ & ++ & ++ & + \\
\hline B/11445 & + & - & ++ & + & ++ & ++ & + & + \\
\hline
\end{tabular}

E: Equine; B: Bovine. (-) absent of antigenic inclusions; (+) 1 to 3 inclusions; (++) few inclusions and negative fields; (+++) homogeneous distribution of inclusions without negative fields. 
Table 4. Sensitivity of the Immunohistochemistry (IHC) in relation to the Fluorescent Antibody Test (FAT).

\begin{tabular}{|c|c|}
\hline \multirow{2}{*}{ CNS REGION } & IHQ Sensitivity \\
\hline & EQUINES BOVINES \\
\hline Hippocampus & $28 \% 87 \%$ \\
\hline Cerebral Cortex & $71 \% 100 \%$ \\
\hline Cerebellum & $87 \% 100 \%$ \\
\hline Brainstem & $75 \% 100 \%$ \\
\hline
\end{tabular}

The incubation period was considered to be the time between inoculation of the samples (performed previously by intracerebral inoculation in mice to isolate the virus) and the appearance of the first symptoms. From data obtained in laboratory routine, it was possible to observe that the minimum incubation period in the animals inoculated with bovine samples was 7 days and the maximum 11 days. The corresponding figures for equine samples were 9 and 14 days, respectively. In the in vivo test, we failed to isolate the virus from two samples of each species.

\section{Discussion}

The present study was carried out through the analysis of epidemiological data as well as of the results acquired previously by conventional techniques; the implementation of the IHQ and in the evaluation of histopathological findings and presence of cellular inclusions of rabies characteristics in brain samples from naturally infected equines and bovines.

According to the epidemiological records for the samples received for laboratory diagnosis, all the animals presented with clinical signs of the disease, the most frequent being depression, uncoordinated gait, lateral decubitus, pedaling movements and finally, paralysis. These findings agree with those reported in the literature (Lima et al., 2005; Pierezan et al., 2007).

The samples came from various municipalities in the state of São Paulo where the hematophagous bat Desmodus rotundus, the main transmitter of rabies in herbivores in Brazil, is found. The presence of this species is reflected in the fact that samples are regularly received from these municipalities for laboratory diagnosis.

Epidemiological surveillance for rabies in herbivores is essential wherever hematophagous bats are found, as natural factors such as the presence of shelter, the availability of food and suitable climatic conditions favor the presence of these animals, which are extremely effective in disseminating the virus, making the disease an enzootic one (Barros et al., 2006).

Studies have shown that the incubation period of the virus from herbivore samples inoculated in mice varies from 7 to 13 days (Silva et al., 2010; Achkar et al., 2010). Here, the virus was isolated in $75 \%$ of the samples, and the incubation period varied from 7 to 14 days. All the animals had the paralytic form of the disease. According to other studies, this form of the disease is associated with lesions in the brainstem and spinal cord and is more common in herbivores (Fernandes \& Riet-Correa, 2007). In a study carried out with bovine and equine samples, Bassuino et al. (2016) showed that lesions were most common in the spinal cord, followed by the brainstem and cerebellum. In the present study, the brainstem was the most affected region, followed by the cerebellum; none of the samples included spinal cord fragments.

Generalized neurodegeneration was observed in all the cases studied. Perivascular accumulation of mononuclear cell infiltrate, particularly lymphocytes and, to a lesser degree, plasma cells and macrophages, was also observed. This profile is characteristic of chronic inflammation, a feature of paralytic rabies caused by the widespread dissemination of the virus as the disease progresses. Involvement of the meninges varied from mild to moderate. These findings agree with those of previous studies (Carlton \& McGavin, 1998), indicating that rabies in herbivores is characterized by degenerative meningoencephalitis.

According to the literature, Negri bodies can be absent in 20 to 60\% of cases (Last et al., 1994; Palmer et al., 1985; Rupprecht et al., 2002). We found inclusions in at least one brain region in all the samples although in different numbers. Analysis of the four brain regions in the eight 
samples for each species using HE revealed inclusions in 62\% of the equine samples and 59\% of the bovine samples. This is a higher figure than in other studies, in which the corresponding figure was 47\% (Green et al., 1992; Lima et al., 2005; Peixoto et al., 2000; Carrieri et al., 2006).

The greatest amount of viral antigen was observed in the cerebellum and brainstem regardless of the technique used (FAT or IHC), agreeing with the findings of previous studies (Langohr et al., 2003; Pedroso et al., 2009, Achkar et al., 2010). For bovine brain samples in paraffin embedded tissue, IHC was more sensitive than FAT. In the equine samples, the technique was more sensitive when used with cerebellum and brainstem samples. These findings confirm that IHC is a suitable alternative technique for laboratory diagnosis of rabies when FAT cannot be used and it is particularly useful for equine samples as FAT can yield many false negative results with this type of sample (Achkar et al., 2010).

More viral antigen was found in the bovine samples than in the equine samples, a finding also reported by Peixoto et al. (2000), who reported that Negri bodies were more common in bovine (80\%) than equines (36\%).

In the present study, $70 \%$ of the animals died a natural death, which may account for the results of FAT and IHC. Infected animals that are euthanized tend to have lower positivity in the diagnostic tests and fewer characteristic histopathological features of rabies. Brain lesions are frequently absent because the clinical course of the disease is interrupted, as is the dissemination of the virus through the CNS. Oliveira et al. (2012) reported 41.6\% positivity in FAT in bovine that died a natural death compared with a figure of $34.08 \%$ in animals that had been euthanized.

Disease progression in equines is faster than in bovines (around 3 to 6 weeks compared with 3 to 15 weeks) and can result in death in as little as 3 or 4 days (Summers et al.,1995) or a decision to euthanize the animal. Our results, which agree with the literature, show that less viral antigen was detected in the equine samples with both techniques, and one sample was negative by IHC. This may be related to the smaller amount of viral antigen in brain tissues in this species (Lima et al., 2005; Achkar et al., 2010).

Previous studies have shown that the number of Negri bodies may be inversely proportional to the degree of inflammation (Cantile \& Youssef, 2016) and that they may be absent in up to 30\% of rabies cases (Last et al., 1994; Palmer et al., 1985; Rupprecht et al., 2002; Faizee et al., 2012). In 37.5\% (24/64) of all the fragments analyzed here, viral inclusions were not observed although an inflammatory process was present. This proportion was slightly higher for bovine brain samples (13/32) than for equine samples (11/32). These findings highlight the importance of submitting samples from suspected rabid animals for diagnostic testing (FAT/IHC) even when there are no apparent abnormal histological findings as they suggest that the histopathological features of rabies are unremarkable.

Farm animals, particularly bovines and equines are considered terminal hosts, on the other hand, are the most affected since they provide great value food to vampire bats, which are important reservoirs of disease. The laboratory diagnosis is essential for an effective epidemiological surveillance be established in a particular region. Our findings reinforce the presence of histopathological changes in the CNS of infected animals not necessarily determines the presence of viral antigen in particular fragment, so, it is necessary the investigation from all CNS ` regions by different diagnostic methodologies.

\section{References}

Acha, P. N., \& Szyfres, B. (1986). Zoonosis y enfermedades transmisibles comunes al hombre y a los animales (2nd ed, pp. 502-526). Washington: Organización Panamericana de la Salud.

Achkar, S., Fernandes, E. R., Carrieri, M. L., Castro, A. B. M., Batista, A. M., Duarte, M. I. S., \& Kotait, I. (2010). Sensibilidade da técnica de Imuno-histoquímica em fragmentos de sistema nervoso central de bovinos e equinos naturalmente infectados pelo vírus da raiva. Pesquisa Veterinária Brasileira, 30(3), 211-218. http:// dx.doi.org/10.1590/S0100-736X2010000300004.

Arelano-Sota, C., Sureau, P., \& Greenhall, A. M. (1971). Preferência de la predación del vampiro a la edad y lar aza del ganado y la época del año. Técnica Pecuária, 17, 23-29.

Assis, R. V. C., \& Rosemberg, S. (1984). Human rabies. Neuropathological study of 30 cases. Revista do Instituto de Medicina Tropical de São Paulo, 26(6), 346-352. http://dx.doi.org/10.1590/S0036-46651984000600010. PMid:6535235. 
Barros, C. S. L., Driemeier, D., Dutra, I. S., \& Lemos, R. A. A. (2006). Doenças do sistema nervoso de bovinos no Brasil (pp 21-28). São Paulo: Vallée.

Bassuino, D. M., Mari, C., Cruz, R. A. S., Boos, G. S., Gomes, D. C., Petinatti, S. P., \& Driemeier, D. (2016). Achados clínicos, patológicos e imuno-histoquímicos em ovinos com raiva. Revista Brasileira de Medicina Veterinaria, 38(1), 86-90.

Bourgon, A. R., \& Charlton, K. M. (1987). The demonstration of rabies antigen in paraffin-embedded tissues using the peroxidase-antiperoxidase method: a comparative study. Canadian Journal of Veterinary Research, 51(1), 117-120. PMid:3552169.

Brasil. Ministério da Saúde. (2008). Manual de diagnóstico laboratorial da raiva. Brasília: Ministério da Saúde.

Brasil. Ministério da Agricultura, Pecuária e Abastecimento - MAPA. (2009). Programa Nacional de Combate a Raiva dos Herbívoros. In Brasil. Ministério da Agricultura, Pecuária e Abastecimento - MAPA. Manual técnico: controle da raiva dos herbivoros (pp. 11-42). Brasília: MAPA.

Braund, K. G., Brewer, B. D., \& Mayhew, I. G. (1987). Inflamatory, infectious, imune, parasitic and vascular diseases. In J. E. Oliver, B. F. Horlein \& I. G. Mayhew (Eds.), Veterinary neurology (pp 254-266). Philadelphia: W.B. Saunders.

Cantile, C., \& Youssef, S. (2016). Nervous system. In M. G. Maxie (Ed.), Jubb, Kennedy, and Palmer's Pathology of domestic animals (6th ed., pp. 251-406). Saint Louis: Saunders Elsevier. http://dx.doi.org/10.1016/ B978-0-7020-5317-7.00004-7.

Carlton, W. W., \& McGavin, M. (1998). Patologia veterinária especial (2. ed., 672 p.). Porto Alegre: ArtMed.

Carrieri, M. L., Peixoto, Z. M. P., Paciencia, M. L. B., Kotait, I., \& Germano, P. M. L. (2006). Laboratory diagnosis of equine rabies and its implications for human postexposure prophylaxis. Journal of Virological Methods, 138(1-2), 1-9. http://dx.doi.org/10.1016/i.jviromet.2006.07.005. PMid:16919789.

Dean, D. J., Abelseth, M. K., \& Atanasiu, P. (1996). Fluorescent antibody test. In F.X. Meslin, M. M. Kaplan \& H. Koprowski. Laboratory techniques in rabies (4th ed., pp. 88-95). Geneva: World Health Organization.

Faizee, N., Hailat, N. Q., Ababneh, M. M., Hananeh, W. M., \& Muhaidat, A. (2012). Pathological, immunological and molecular diagnosis of rabies in clinically suspected animals of different species using four detection techniques in Jordan. Transboundary and Emerging Diseases, 59(2), 154-164. http://dx.doi.org/10.1111/j.18651682.2011.01255.x. PMid:22390575.

Fernandes, C. G., \& Riet-Correa, F. (2007). Raiva. In F. Riet-Correa, A. L. Schild, R. A. A. Lemos, \& J. R. J. Borges (Eds.), Doenças de ruminantes e equídeos (Vol. 1, pp. 184-198, 719p.). Santa Maria: Pallotti.

Fernandes, E. R., Andrade Junior, H. F., Lancellotti, C. L. P., Quaresma, J. A. S., Demachki, S., Vasconcelos, P. F. C., \& Duarte, M. I. S. (2011). In situ apoptosis of adaptive immune cells and the cellular escape of rabies virus in CNS from patients with human rabies transmitted by Desmodus rotundus. Virus Research, 156(1-2), 121-126. http://dx.doi.org/10.1016/j.virusres.2011.01.006. PMid:21255623.

Forattini, O. P. (1980). Epidemiologia geral (pp. 117-131). São Paulo: Artes Médicas.

Fundação Nacional da Saúde - FUNASA, Ministério da Saúde. (1996). Morcegos em áreas urbanas e rurais: manual de manejo e controle (pp. 117). Brasília: Gráfica e Editora Brasil.

Gonçalves, M. A. S., Sá-Neto, R. J., \& Brazil, T. K. (2002). Outbreak of aggressions and transmission of rabies in human beings by vampire bats in northeastern Brazil. Revista da Sociedade Brasileira de Medicina Tropical, 35(5), 461-464. http://dx.doi.org/10.1590/S0037-86822002000500006. PMid:12621664.

Green, S. L., Smith, L. L., Vernau, W., \& Beacock, S. M. (1992). Rabies in horses: 21 cases (1970-1990). Journal of the American Veterinary Medical Association, 200(8), 1133-1137. PMid:1607322.

International Committee on Taxonomy of Viruses - ICTV. (2016). Virus Taxonomy. Available at: https://talk. ictvonline.org/taxonomy/p/taxonomy-history?taxnode_id=19710311\&src=NCBI\&ictv_id=19710311(accessed 25 September 2019)

Johnson, N., \& Montano Hirose, J. A. (2018). The impact of paralytic bovine rabies transmitted by vampire bats in Latin America and the Caribbean. Revue Scientifique et Technique (International Office of Epizootics), 37(2), 451-459. http://dx.doi.org/10.20506/rst.37.2.2814. PMid:30747135.

Koprowski, H. (1996). The mouse inoculation test. In F.-X. Meslin, M. M. Kaplan, \& H. Koprowski. Laboratory techniques in rabies (4th ed., pp. 80-87). Geneva: World Health Organization.

Langohr, I. M., Irigoyen, L. F., Lemos, R. A. A., \& Barros, C. S. L. (2003). Aspectos epidemiológicos, clínicos e distribuição das lesões histológicas no encéfalo de bovinos com raiva. Clínica Rural, 33(1), 125-131.

Last, R. D., Jardine, J. E., Smit, M. M., \& van der Lugt, J. J. (1994). Application of immunoperoxidase techniques to formalin-fixed brain tissue for the diagnosis of rabies in southern Africa. The Onderstepoort Journal of Veterinary Research, 61(2), 183-187. PMid:7541123.

Lima, E. F., Riet-Correa, F., Castro, R. S., Gomes, A. A. B., \& Lima, F. S. (2005). Sinais clínicos, distribuição das lesões no sistema nervoso e epidemiologia da raiva em herbívoros na região Nordeste do Brasil. Pesquisa Veterinária Brasileira, 25(4), 250-264. http://dx.doi.org/10.1590/S0100-736X2005000400011.

Marcolongo-Pereira, C., Sallis, E. S. V., Grecco, F. B., Raffi, M. B., Soares, M. P., \& Schild, A. L. (2011). Raiva em bovinos na Região Sul do Rio Grande do Sul: epidemiologia e diagnóstico imuno-histoquímico. Pesquisa Veterinária Brasileira, 31(4), 331-335. http://dx.doi.org/10.1590/s0100-736X2011000400010. 
Maxie, M. G., \& Youssef, S. (2007). The nervous system. In M.G. Maxie (Ed.), Jubb, Kennedy, and Palmer's pathology of domestic animals (5th ed., Vol. 1, pp. 283-455). W.B. Saunders, Philadelphia.

Mochizuki, N., Kawasaki, K., Silva, M. L. C. R., Afonso, J. A. B., Itou, T., Ito, F. M., \& Sakai, T. (2012). Molecular epidemiology of livestock rabies viruses isolated in the northeastern Brazilian states of Paraíba and Pernambuco from 2003-2009. BMC Research Notes, 5(32), 1-7. http://dx.doi.org/10.1186/1756-0500-5-32. PMid:22243739.

Oliveira, T. S., Bull, V., Rezende, C. A., Furtini, R., Costa, E. A., Paixão, T. A., \& Santos, R. L. (2012). Perfil das amostras do sistema nervoso central de bovinos com síndrome neurológica e diagnóstico da raiva bovina no serviço de defesa sanitária de Minas Gerais, 2003-2010. Pesquisa Veterinária Brasileira, 32(4), 333-339. http://dx.doi. org/10.1590/s0100-736X2012000400010.

Palmer, D. G., Ossent, P., Suter, M. M., \& Ferrari, E. (1985). Demonstration of rabies viral antigen in paraffin tissue sections: comparison of the immunofluorescence technique with the unlabeled antibody enzyme method. American Journal of Veterinary Research, 46(1), 283-286. PMid:3882030.

Pedroso, P. M. O., Colodel, E. M., Pescador, C. A., Arruda, L. P., \& Driemeier, D. (2009). Aspectos clínicos e patológicos em bovinos afetados por raiva com especial referência ao mapeamento do antígeno rábico por imuno-histoquímica. Pesquisa Veterinária Brasileira, 29(11), 899-904. http://dx.doi.org/10.1590/ S0100-736X2009001100006.

Peixoto, Z. M. P., Cunha, E. M. S., Souza, M. C. A. M., Silva, L. H. Q., Carrieli, M. L., \& Lazarini, S. R. F. (2000) Diagnóstico laboratorial da raiva dos herbivoros: aspectos peculiares. In Seminário Internacional de Raiva (51 p.). São Paulo: Instituto Pasteur.

Pierezan, F., Lemos, R. A. A., Rech, R. R., Rissi, D. R., Kommers, G. D., \& Cortada, V. C. L. M. (2007). Raiva em equinos. In Anais do XIII Encontro Nacional de Patologia Veterinária (pp. 145-146). Campo Grande, MS: Universidade Federal de Mato Grosso do Sul.

Rech, R., Rissi, D. R., Silva, M. C., Inkelmann, M. A., \& Barros, C. S. L. (2006). Histomorfologia do gânglio de Gasser, da rete mirabile carotídea e da hipófise de bovinos: estudo de 199 casos. Pesquisa Veterinária Brasileira, 26(2), 105-111. http://dx.doi.org/10.1590/s0100-736X2006000200008.

Rupprecht, C. E., Hanlon, C. A., \& Hemachudha, T. (2002). Rabies re-examined. The Lancet. Infectious Diseases, 2(06), 327-343. http://dx.doi.org/10.1016/S1473-3099(02)00287-6. PMid:12144896.

Schmidt, K. M., \& Badger, D. D. (1979). Some social and economic aspects in controlling vampire bats. Proceedings of the Oklahoma Academy of Science, 59, 112-114.

Silva, M. L. C. R., Riet-Correa, F., Galiza, G. J. N., Azevedo, S. S., Afonso, J. A. B., \& Gomes, A. A. B. (2010). Distribuição do vírus rábico no sistema nervoso central em ruminantes naturalmente infectados. Pesquisa Veterinária Brasileira, 30(11), 940-944. http://dx.doi.org/10.1590/S0100-736X2010001100007.

Singh, R., Singh, K. P., Cherian, S., Saminathan, M., Kapoor, S., Manjunatha Reddy, G. B., Panda, S., \& Dhama, K. (2017). Rabies - epidemiology, pathogenesis, public health concerns and advances in diagnosis and control: a comprehensive review. The Veterinary Quarterly, 37(1), 212-251. http://dx.doi.org/10.1080/01652176.2017.13 43516. PMid:28643547.

Summers, B. A., Cummings, J. F., \& De Lahunta, A. (1995). Veterinary neuro-pathology (527p.). St Louis: MosbyYear Book.

Swanepoel, R. (2004). Rabies. In J. A. W. Coetzer \& R. C. Tustin (Eds), Infections diseases of livestock (2nd ed., Vol. 2, pp. 1123-1182). Cape Town: Oxford University Press.

Webster, W. A., \& Casey, G. A. (1996) Virus isolation in neuroblastoma cell culture. In F.-X. Meslin, M. M. Kaplan \& H. Koprowski. Laboratory techniques in rabies (4 ${ }^{\text {th }}$ ed., pp 96-104). Geneva: World Health Organization. 